Flint, A. G. (2020). 'African Witchdoctors' and Popular Culture: Global Hierarchies and the Reinforcement of the Colonial World Order. Journal of Contemporary African Studies.

https://doi.org/10.1080/02589001.2020.1836331, https://doi.org/10.1080/02589001.2020.1836331

Peer reviewed version

Link to published version (if available):

10.1080/02589001.2020.1836331

$10.1080 / 02589001.2020 .1836331$

Link to publication record in Explore Bristol Research

PDF-document

University of Bristol - Explore Bristol Research

General rights

This document is made available in accordance with publisher policies. Please cite only the published version using the reference above. Full terms of use are available:

http://www.bristol.ac.uk/red/research-policy/pure/user-guides/ebr-terms/ 
'African Witchdoctors' and Popular Culture: Global Hierarchies and the

Reinforcement of the Colonial World Order

\begin{abstract}
Adrian Flint
School of Sociology, Politics and International Studies (SPAIS), University of Bristol, Bristol, United Kingdom
\end{abstract}

\begin{abstract}
Author
Adrian Flint is a Senior Lecturer in Development Politics at the School of Sociology, Politics and International Studies (SPAIS) at the University of Bristol. His main research interests lie within the field of North-South relations and include issues like health and development (particularly HIV and AIDS), global trade, poverty alleviation, and sustainable development. He can be contacted at:
\end{abstract}

Adrian.Flint@bristol.ac.uk

SPAIS, University of Bristol

11 Priory Road

Bristol

BS8 1TU, United Kingdom

Published in the Journal of Contemporary African Studies

DOI: https://doi.org/10.1080/02589001.2020.1836331 


\title{
'African Witchdoctors' and Popular Culture: Global Hierarchies and the Reinforcement of the Colonial World Order
}

\begin{abstract}
This paper makes the case for a closer study as to how Africa and African people are portrayed within popular culture in the Global North, adding to the discussion surrounding the importance of 'low politics' in producing and reproducing global hierarchies. It focuses on representations of African traditional healers in Anglo-American popular culture as a way of highlighting deeply entrenched outsider 'understandings' of the continent. The colonial trope of the 'African witchdoctor' has remained a fixture in the collective Anglo-American cultural imagination since the days of $\mathrm{H}$. Rider Haggard. Evidence demonstrates that these colonial stereotypes have remained remarkably durable, having seen little change in over one hundred and fifty years. Following Cynthia Enloe (1996), this paper argues that, in the interests of gaining a deeper appreciation of the power structures shaping African 'development', the realm of the 'imaginary' and the 'made up' where popular culture is concerned, demands greater scrutiny.
\end{abstract}

KEYWORDS: Africa, colonial tropes, traditional healers, popular culture, witchdoctor

\section{Introduction}

Much of my work as a researcher has been in the field of health and development, with a particular focus on Africa. ${ }^{1}$ One of my areas of interest is the importance of traditional forms of healing to people's perceptions and sense of health and wellbeing. The prompt for this particular paper stems from some of the conversations I have had with people in the UK who have enquired about my work. I continue to be surprised by the regularity with which people 
make inappropriate 'jokes' about 'witchdoctors', 'voodoo' and 'curses', marvelling (quite often with eye rolls) at the 'exotic' nature of it all. When challenged on the basis for their views, people tend to struggle to find concrete reference points, reaching instead for vague references to television or films. Why this casual disdain for African healers, when, arguably, few in the Global North would admit to having a 'conscious' viewpoint on the issue?

Despite millions of people in Africa engaging with traditional healers (WHO 2019, 59), the term 'African witchdoctor', laden with centuries of colonial baggage, remains a mainstay in the Anglo-American cultural landscape. This is critical. While the overtly racist language employed during the colonial era in European descriptions of the continent has to a certain extent been blunted, many underlying conceptualisations remain the same. This holds true for a variety of economic, social, and cultural issues and contexts (Duffield 2007; Hewitt 2006; Flint and Hewitt 2015). Conrad's ([1899]1999) Heart of Darkness remains a benchmark where outsider 'understandings' of Africa are concerned: Africa is 'enigmatic', 'unknowable' and, importantly for the purposes of this paper, 'irrational'. The result is that, despite the centrality and relevance of traditional healers to communities across the continent, the foundations, practices, practitioners and users of traditional healing are essentially stereotyped as 'primitive' and 'backward'. Far from being simply linked to 'entertainment', the ways in which African healers are portrayed within Anglo-American popular culture form part of a wider - deeply embedded - construction of Africa and African people. This construction in turn serves to reinforce international power hierarchies and helps to shape the notion of African 'development' and how it should be practiced. After all, policymakers are not operating within a vacuum. Rather, they function within established cultural frameworks that determine how they make sense of the world around them (Hall 1997; Shapiro 1992; Weldes 1999; 2003). It is only by scrutinising the seemingly less obvious sites in which 
power is produced and reproduced, that a more comprehensive picture as to how global hierarchies are sustained can be arrived at (Enloe 1996).

Accordingly, this paper highlights the deep-rooted and problematic casual denigration of African traditional healers as represented by the trope of the 'African witchdoctor' in popular culture. A stalwart of the colonial-era imagination, this trope has, over the past century and a half, received constant socio-cultural reinforcement within a range of popular culture genres: adventure and pulp fiction; Hollywood blockbusters; television; online roleplaying games. These representations may not be intended to be 'real'. At the same time, they contribute significantly to a 'reality' that shapes outsider understandings of Africa and its challenges.

\section{Illness, culture and healers}

There is a much-quoted World Health Organisation (WHO) statistic that suggests that up to $80 \%$ of African people regularly engage with traditional healers (WHO 2002; 2008). While this figure is questionable (Nattrass 2008), it is nevertheless the case that traditional healers remain integral to the lives of millions of people across the continent (WHO 2019, 59). Importantly, traditional healers practice not only in rural areas, and areas where biomedical practitioner-to-patient ratios are poor. Recourse can also be high in urban areas and in comparatively wealthy regions (a walk through any urban centre in the regional economic powerhouse of South Africa, with multiple traditional surgeries and pharmacies in evidence, indicates the enduring popularity of traditional healers). Even in instances in which biomedical practitioners are more readily available, many people in African countries demonstrate a preference for 'medical pluralism', engaging simultaneously with traditional and biomedical systems (Flint 2015; Dickinson 2014). The key point is that many African 
people actively choose to engage with traditional healers because they perceive them to have insights over and above that which their biomedical equivalents can provide. ${ }^{2}$

Evidence indicates that 'medical pluralism' can result in improved healthcare outcomes for patients. In the United States, the Indian Health Service (IHS), the main federal healthcare provider for Native Americans, has a long history of accommodating both biomedical and traditional healers. Starting in the 1950s, the IHS began to employ 'culturally appropriate' forms of healing, bringing traditional healers into the formal healthcare system. The result was a significant improvement in therapeutic outcomes. ${ }^{3}$ The IHS experience has shown that traditional healers' techniques can be most effective in treating alcohol and drug addiction, and mental health conditions such as depression (Flint 2015). The evidence from the United States also demonstrates that medical pluralism need not be problematic and that patients can navigate two wholly different healthcare cosmologies without undermining outcomes. Similarly, the IHS has shown that patient engagement with traditional healers does not necessarily affect self-compliance with respect to biomedical prescriptions (Kim and Kwok 1998). ${ }^{4}$ Broadly speaking, within the context of the IHS, engagement with different types of healers has been shown to be self-reinforcing.

Despite the above, the ways in which African healers have been (and continue to be) portrayed in Anglo-American popular culture point to outsider representations of African people's 'irrationality'. This is largely because the basis for African systems of traditional healing remains misunderstood; it is this misunderstanding (or failure to understand) that lies at the heart of the ongoing employment of the 'African witchdoctor' trope. Much of this 'misunderstanding' stems from a perceived superiority of biomedicine (with its accompanying 'scientific method') by those in the Global North. For Frantz Fanon, the preeminence of biomedicine and its practitioners should be understood not as a reflection of efficacy with respect to medical outcomes, but as a result of Western cultural and political 
domination. In A Dying Colonialism he argues that biomedicine formed part of the colonial process of subjugation, that 'the doctor always appears as a link in the colonialist network, as a spokesman for the occupying power' (Fanon 1965, 131). In a similar vein, Okere $(2005,27)$ argues that the 'universality' of biomedicine 'can only be qualified as usurpation'. The fact that in the Global North biomedicine is regularly referred to as 'modern medicine' (Wasunna 2012, 313), in contrast to that practiced by African traditional healers, is indicative of a binary mindset that separates healers into two camps: 'rational' and 'modern' (biomedical) and 'irrational' and 'primitive' (traditional).

African people's experiences and realities have long been understood and articulated by those in the Global North in ways that fail to convey the subtleties and nuances necessary to express the significance of the former (Mkhize, Dumisa and Chitindingu 2014). The use of the term 'African witchdoctor' is in itself inadequate and limiting in a number of ways. Firstly, its use perpetuates the outsider view of Africa as a homogenised sociocultural mass, ignoring the fact that traditional healers (and their methods) vary across the continent; it fails to convey the different areas of specialisation covered by the term, ignoring the fact that there are traditional bone setters, traditional birth attendants, traditional surgeons, herbalists, diviners, and faith healers. Secondly, the term 'witchdoctor' obscures the positive connotations associated with traditional healers within their communities - to illustrate just one case, the term for a diviner-healer within Zulu culture is a sangoma. A sangoma is a practitioner of ngoma, a term that has its linguistic root in the word for 'drum'. As a practice, ngoma is widely recognized as 'connoting performance, drumming, dancing, celebration, and ritual therapy' (Janzen 1992, 21), something far removed from the more sinister overtones usually associated with the term 'African witchdoctor'. Within this ngoma tradition, understandings of illness and healing extend beyond the confines of medical practice as it is understood in the Global North. Sangomas are more than simply 'medical doctors', their 
approach to healing is far more holistic. As part of their broader role in maintaining people's wellbeing, sangomas also act as advisors, conciliators, and therapists within their communities (Ngubane 1977).

Africa is, as stated, far from culturally or socially homogenous. At the same time, certain commonalities, broadly speaking, exist where the practices of traditional healers are concerned (Janzen 1992). For a meaningful - as opposed to lazily stereotypical understanding of what African traditional healers do, outsiders need to get to grips with the existence of what Adam Ashforth $(2000 ; 2001)$ has described as the 'witchcraft paradigm'. Across much of Africa - see, for example, Central Africa (Devisch 2005), West Africa (Iroegbi 2005), East Africa (Ndege 2017), and southern Africa (Ngubane 1977) - the 'witchcraft paradigm' lies at the centre of most forms of traditional healing. In many African cosmologies the line between the corporeal and spiritual domains is blurred, and the spirits of departed ancestors are believed to play a determining role in people's lives, for good and for ill (Mpofu 2011). A key aspect of a traditional practitioner's work involves acting as a conduit between these respective domains. ${ }^{5}$ For the most part, African traditional healers base their work on directives from the spiritual realm - from whence the ancestors of traditional healers are claimed to act as directors and mentors. The pharmaceutical properties of healing ingredients are far less integral to the treatment process than their supernatural qualities; each remedy is tailor-made by the healer for each patient. In this sense, much of a traditional healer's work tends to be directed specifically at fighting malevolent spiritual forces, often 'witchcraft'-related, rather than viruses and biomedically-defined conditions.

The 'body parts' approach to healing that is a feature of biomedicine (Okere 2005, 30), is alienating for many people in Africa; engagement with traditional healers offers people the opportunity for treatment within a culturally-relatable framework. Furthermore, not only do traditional healers tend to be more focused on the 'whole', treatments tend to be 
immersive and often communal, ensuring that an individual's health is also a matter for the community at large. Given the spiritual dimension of much of their work, traditional healers are also able to help clients make sense of their suffering in existential terms. This is in stark contrast to many people's experience with biomedical practitioners in which they are assessed in short expert-led, business-like consultations that offer little scope for questions or reflection. Moreover, the randomness of the 'germ theory' of disease which forms the basis for much of the biomedical model, offers little solace to those seeking answers to the question 'why me?'.

Despite the evidence from, for instance, the IHS, that traditional healers can play an important role in improving healthcare outcomes, racist stereotyping of African traditional healers continues to undermine and demean people's engagement with these practitioners. A predisposition by those in the Global North to view African traditional healers through anything other than an Enlightenment lens means that those who choose to engage with African traditional healers tend to be dismissed as 'superstitious', 'uneducated' and 'gullible'. This paper demonstrates how entrenched negative perceptions of African traditional healers remains embedded in the Anglo-American cultural consciousness. It indicates that the casual way in which such portrayals dismiss the cultural and medical potential of African traditional healers serves to reinforce the Othering of African people, and highlights how related narratives serve to maintain and buttress global hierarchies. In short, it highlights the degree to which 'the virus of racism subsists with seeming immortality' in the Global North (Ramose 2016, 67).

\section{Popular culture as a site of power}

The negative depiction of African healers in Anglo-American popular culture appears to be, on the face of it, a relatively secondary issue given wider healthcare and development issues 
affecting Africa: HIV and AIDS, Ebola, malaria, and neglected tropical diseases, alongside underdeveloped healthcare infrastructure and more general environmental factors facilitating the spread of disease. African healers as portrayed in books and films, and on television and in games may seemingly have little relevance to debates on these issues. Popular culture is, of course, understood to be largely about entertainment. It invites an escape from, rather than the recreation of, reality. Researchers in development should, it can be argued, concern themselves with issues of more clear-cut academic and social relevance, such as those intertwined with the Sustainable Development Goals (SDGs).

With respect to international relations, Cynthia Enloe $(1996,200)$ highlights the relevance of 'low' politics where a deeper understanding of the production and reinforcement of power relations is concerned. While not discounting 'high' politics, scrutiny of the 'trivial' can reveal a multiplicity of otherwise overlooked sites of power, and help to strip bare the platforms and frameworks of these. Revealing the 'political' in the ostensibly 'non-political' brings us closer to the mechanisms of the exercise of power; tandem engagement with 'high' and 'low' politics highlights their symbiotic relationship (Weldes 2003, 5).

Popular culture is the site of a great deal more 'political work' than is generally acknowledged; its role in enforcing political systems and hierarchies should not be underestimated. As Cynthia Weber $(2014,272,274)$ argues, 'culture is political, and politics is cultural'. Drawing on Antonio Gramsci's exposition on 'folklore' $(2000,323)$ and Theodor Adorno and Max Horkheimer's (1979) concept of 'standardization' in the cultural realm, Michael Shapiro $(1992,1)$ highlights popular culture's tendency to 'endorse prevailing power structures by helping to reproduce the beliefs and allegiances necessary for their uncontested functioning'. This is because, as Stuart Hall $(1997,18)$ has outlined, culture is about a system of 'shared meanings' and 'shared conceptual maps'. In this way, popular culture plays something of a 'constitutive function' that allows us to 'construct a reality' with respect to the 
world around us (Rowley 2010, 362). In essence, popular culture is a significant conduit for societal constructions of collective 'common sense' understandings of the world. In turn, the manufacture of 'common sense' broadens into a 'manufacturing of consent' - a subliminal validation of extant power structures (Weldes 1999, 119). The study of popular culture, then, is critical in terms of the extent to which it 'offers clear and direct representations of themes central to [the maintenance of power structures]' (Weldes 2003, 11).

Fictitious representations of African traditional healers therefore, while 'not real' and obviously 'imagined', do not exist in a vacuum. Rather, they form part of a broader, deeper and older outsider narrative on Africa generally, and on issues of African development in particular. Consciously or unconsciously, these long-established tropes frame and inform relationships between African countries and the Global North. In this sense, the ongoing Othering of African people feeds into the expert-led attitude to development that characterises much of the Global North's approach to 'saving' Africa. Furthermore, such tropes should be viewed as contributing to the scaffolding that reinforces the continuation and maintenance of global power asymmetries that have their origin in the colonial era (Kothari 2009, Hewitt 2006). ${ }^{6}$ Given that 'developing Africa' is very much a project of the Global North, acknowledging the 'trivialities' underpinning narratives of Africa forms part of the critical exercise in 'explicit political accounting' advocated by Enloe $(1996,200)$ as a means of exploring and exposing international power hierarchies.

\section{'African witchdoctors' in nineteenth-century non-fiction}

The 'African witchdoctor' is a well-worn trope that appears time and again within colonialera discourses. The narratives detailed below represent, in many ways, a classic case of 'Othering', with African people depicted as 'irrational, depraved (fallen), childlike, "different"' (Said 1995, 48). What follows, while by no means exhaustive, is an overview of 
the degree to which the 'African witchdoctor' trope became a fixture within Anglo-American popular culture to the point that it has, arguably, come to underpin broader ideas of 'Africanness', and specific perspectives on African traditional practitioners and their patients.

Pre-Scramble, first-hand non-fiction British accounts of traditional healers and their practices in Africa tended to be, to a degree at least, constructive. Mungo Park, medically trained and one of the earliest dedicated European explorers of Africa, was a respectful observer of African healers during his late eighteenth-century trips up the Niger River as detailed in his Travels in the Interior of Africa (1799). David Livingstone, arguably the most renowned African explorer of his day, also had a medical background and, in the course of his travels between 1845 and 1873, took a specific interest in African approaches to healing. His Missionary Travels and Researches in South Africa (1857) and A Popular Account of Livingstone's Expedition to the Zambesi and its Tributaries (1875), make regular reference to the practices of local healers. Richard Francis Burton, famous for his visit to Mecca and his exploration, alongside John Hanning Speke, of Africa's Great Lakes, although frequently pejorative about and dismissive of African cultures, was not above engaging with African traditional healers; in First Footsteps in East Africa (1856), he details being treated by a Somali healer.

Towards the late nineteenth century European discourses on race and hierarchy began to take on more overt social Darwinian overtones, and commentary on African healers and their healing practices began to set within the parameters of a hardening social orthodoxy (Brantlinger 1985). Ideas of 'medicine men' and 'medicine women' were replaced with something altogether more pejorative. Contemporary Times reporting revelled in lurid details of 'witchdoctor'-led violence, brutality and dissent, both within communities and, significantly, pitting 'gullible' local populations against the incipient colonial order. 
Healers' traditional role at the heart of African leadership saw them reported as threats to the British 'civilising mission'. A description of the 'Ninth Frontier War' (South Africa, 1877-1878) highlighted the 'naivety' of Xhosa fighters' faith in their 'witchdoctor' commander, and, by extension, provided readers with a justification for British military aggression and colonial expansion:

[t]he attack ... was [led] by Gneto, the witch doctor ... [who] had doctored both Galekas and Gaekas by painting them with a broad stripe of paint on the forehead ... a charmed necklace had been served out to each man, made of string or sinew, with a piece of wood hanging from it, which if they bit during the fight would keep them from being shot ... It is sad to reflect that there should still be a race, with certainly some good qualities, living on the verge of civilization ... which should still believe such utter nonsense ... (The Times 1878, 3).

A report of the 'First Matabele War' (Zimbabwe, 1893-1894) brought British readers graphic purported details of an execution at the hands of the Ndebele King Lobengula's 'witchdoctor' who:

[g]ouged a woman's eyes out with an assegai and then [threw] her into a pool of the river to be devoured by the crocodiles ...[T]he ... witch doctor was a very terrible person; for he used to smell towards the north far beyond the Zambesi and in all directions, and whatever man he smelt out had his brains knocked out... (The Times 1894, 6). 
The one-sided negotiations that concluded the 'First Matabele War' curtailed significantly the practices - and authority - of traditional healers on the grounds of their 'malign influence'. For Dr Leander Starr Jameson, an ally of Cecil Rhodes and a key player in the negotiations:

[W]itch-doctors exert an immense influence, always for evil, over the minds of these superstitious people; horrible cruelties and all manner of crimes have been perpetrated by them. Witchcraft as practiced here is invariably the prelude to murder and should be stamped out ... (The Times 1894, 7).

The descriptions continued to flow during the First Chimurenga (the 'Second Matabele War', 1896-1897): 'witchdoctors' were 'devious', their followers 'gullible' - with the result being 'needlessly' protracted African resistance to colonial encroachment:

The surrender and imprisonment of Kagube, the notorious witch-doctor ... is one of the most important episodes of the tedious native war...The natives used to flock to him from all parts ... he speedily acquired great wealth and enormous influence ...[H]e promised to give charms to all who would fight, and to render them proof against the bullets of the white man, which would turn into water or drop harmless from the mouths of those they struck ... This superstition has prolonged the war long after it should have died out, and has rendered the task of reducing the natives to subjugation harder (The Times 1897, 5).

The 'crimes' of 'witchdoctors' constituted an important aspect of the reconstruction of British aggression in Africa as a series of 'civilising' missions, with African healers' integral role in 
leadership and resistance becoming in the process repackaged and re-presented as evidence of African people's need of 'saving' from the 'primitive' and 'primordial'.

\section{'African witchdoctors' in pulp fiction and film}

Pulp fiction both fed into and fed off highly coloured 'non-fiction' representations and interpretations of African resistance - of communities shaken to the core by the inroads of colonial advance. Works of $\mathrm{H}$ Rider Haggard and H G Wells, published in the 1880s and 1890s, contained early examples of the emergent 'witchdoctor' trope that has, within the Anglo-American imagination, displayed remarkable durability (Haggard 1885; 1892; 1896; Wells 1897). 'Witchdoctor' portrayals were cemented subsequently within the pulp fiction made famous in the early twentieth century through the work of, amongst others, Edgar Rice Burroughs (2014), Robert E. Howard (1928; 1930; 2007) and Charles Beadle (1922). It is, arguably, these representations in popular culture that served to normalise, sustain and entrench pejorative narratives relating to African healers and African forms of traditional healing.

H Rider Haggard's 'boy's own' adventures in the African hinterland captured the late nineteenth-century imagination, and went on to shape profoundly the twentieth-century template of the 'African witchdoctor'; a television mini-series starring Patrick Swayze based on Haggard's seminal King Solomon's Mines (first published in 1885) was released in the US as recently as 2004. Edgar Rice Burroughs' enduringly popular Tarzan series (the first book, Tarzan of the Apes, appeared in 1914) provided an even more lurid, and equally popular, view of 'African witchdoctors' (see, for example, the Jungle Tales of Tarzan, first published in 1919). The Tarzan character, over a century old, continues to attract large audiences: The Legend of Tarzan, a major cinema release starring Alexander Skarsgård, was a notable box office success in 2016. Robert E Howard's long running Solomon Kane series also served to 
entrench the 'witchdoctor' trope. The Solomon Kane character first appeared in $1928^{7}$, and the film adaptation Solomon Kane went on cinema release in 2009. Charles Beadle never matched Haggard, Rice Burroughs and Howard in extended popularity, but his pulp fiction novel Witch-Doctors, published in 1922 and also tapping into imperial 'boys own' themes, attracted a wide readership during the inter-war period.

The emergent 'witchdoctor' figure became, in a remarkably short space of time, a settled cliché: primal and repulsive, devious and dangerous. In King Solomon's Mines, the most famous of Haggard's works, the 'witchdoctor' Gagool is a woman of considerable age. She is variously described as corpse-like, monkey-like, and cobra-like. She is cruel and takes pleasure in bringing death. In short, she is bestial and inhuman. Haggard (1885, 146) describes a 'sniffing out' scene in which Gagool and her attendants seek out enemies of the king:

Quicker and quicker she danced, till she lashed herself into such a frenzy of excitement that the foam flew in flecks from her gnashing jaws, her eyes seemed to start from her head, and her flesh to quiver visibly. Suddenly she stopped dead, and stiffened all over, like a pointer dog when he scents game, and then with outstretched wand began to creep stealthily towards the soldiers before her ...

Beadle's $(1922,22)$ Witch-Doctors likewise emphasises the 'evil' and bestial nature of 'witchdoctors'. His 'witchdoctor' character Bakahenzie engages in a 'sniffing out' that leads to the strangulation of an innocent man:

The drums broke into a hysterical rhythm. Bakahenzie leaped high in the air; whirled around and around screaming hoarsely; leaped and spun continually ... He whirled 
and screamed in front of the King and fell headlong, as if in a fit, with eyes injected and foam upon the black tufts of beard. Bakahenzie clutched his belly and began to howl like a hyena at the moon.

However sensational their descriptions, Britons Haggard and Beadle might have drawn, at least to some extent, on their African experiences. Haggard participated in South African colonial administration, and Beadle served in the Southern Rhodesian (Zimbabwe) British South Africa Police, and fought in the South African War. Americans Burroughs and Howard had no direct experience of Africa; in some instances, then, the crude foundations for the 'witchdoctor' trope are based on little more than imagination.

In Tarzan, the 'witchdoctor' Bukawai, who has hyenas as his 'constant companions', is an aged and repulsive practitioner of deception, preying on the gullibility of local people:

Bukawai sat down beneath a tree ... He did not fear harm at the hands of these people of another tribe, although he well knew that they must fear and hate him. His leprosy alone would prevent their laying hands upon him, while his reputation as a witch-doctor rendered him doubly immune from attack (Rice Burroughs 2014, 499).

In Howard's (2007, 42) adventures of Solomon Kane, the 'witchdoctor' N'longa, while an ally of the protagonist, remains morally ambiguous and shares similar animalistic characteristics with the creations of Haggard, Beadle and Rice Burroughs:

...lean, withered and wrinkled. The only thing that seemed alive about him were his eyes, and they seemed like the eyes of a snake. [He was] naked save for a loin-cloth 
and the usual paraphernalia of bracelets, anklets and armlets. Weird fetishes of ivory, bone and hide, animal and human, adorned his arms and legs.

In King Solomon's Mines, the British heroes avoid execution through a demonstration of their own 'magical powers' thanks to their prior knowledge of an impending lunar eclipse. By contrast, 'child-like' Africans are terrified - a 'groan of terror rose from the onlookers ... we found crowds of men huddled together in the utmost consternation at the natural phenomenon which they were witnessing' (Haggard 1885, 30). The idea that 'science trumps superstition', the underlying theme within many of these colonial-era stories, further buttressed the narrative of the superiority of 'European-ness'.

\section{'African witchdoctors' in contemporary popular culture}

The 'African witchdoctor' trope continues to exhibit conspicuous and problematic longevity within the popular culture of the Anglo-American world. 'Witchdoctor' depictions remarkably similar to those of Haggard et al continue to appear time and again across a range of latter-day cultural platforms. Contemporary books, films, television programmes and, most recently, computer and video games, continue to oxygenate colonial-era stereotypes, thus helping to imbue twenty-first century perspectives on African traditional healers with the loaded constructions of an earlier mindset.

Wilbur Smith, Zambian-born, and the author, since 1964, of some 40 bestselling novels, has arguably been the doyen of African adventure fiction for many decades. His depictions of 'witchdoctors' in works like A Falcon Flies (1980), Men of Men (1981), The Leopard Hunts in Darkness (1984), Rage (1987), Elephant Song (1992) and Assegai (2009), all conform to the Haggard 'witchdoctor' template. ${ }^{8}$ The characters tend to be old, seminaked, dressed in skins and adorned with bones, and either 'evil' or morally ambiguous. 
Largely negative depictions can also be found beyond the conventional African adventure genre. In Barbara Wood's Kenyan-based Green City in the Sun (1988), a missionary family is 'cursed' by a 'medicine woman'; in Barbara Kingsolver's The Poisonwood Bible (1998), a 'witchdoctor' hides a venomous snake in the family's chicken coop (and stands out physically; one of his feet has six toes); Hari Kunzru's award-winning The Impressionist (2003) has its denouement in West Africa, where the protagonist is ritually tortured by a 'witchdoctor'. Mo Hayder's bestselling Ritual (2008), set in the UK, links 'African rituals' to 'black magic' and the 'harvesting' of body parts. Works like Nancy Farmer's Zimbabwean science-fiction novel The Ear, The Eye and the Arm (1994), and Isabelle Allende's Forest of the Pygmies (2005) extend 'witchdoctor' stereotyping to the 'young adult' market.

Where film and television are concerned, White Witch Doctor (1953), based on the novel of the same name, and starring Susan Hayward and Robert Mitchum, pits an old Congolese 'witchdoctor', 'malicious, and steeped in wickedness', against a white American nurse (for the novel, see Stinetorf 1950). In Tarzan's Fight for Life (1958), one of the white characters comments that 'witchdoctors have no power over sickness', to which Tarazan replies gravely that 'they have big power over their people'. Tarzan then goes on to battle the 'witchdoctor' who tasks his followers with bringing him Tarzan's heart. The Witches, a 1966 Hammer horror film starring Joan Fontaine, starts with the heroine, a white mission schoolteacher in colonial Africa being attacked by a masked 'witchdoctor' (the 'witchdoctor' is leading a rebellion). The big-budget apartheid-era South African mini-series charting the rise of Shaka Zulu, the nineteenth-century architect of the Zulu Empire (Shaka Zulu; 1986), presents its elderly, red-eyed 'witchdoctor' as 'the nameless one' - one of a line-up of profoundly stereotyped Zulu characters. In low-budget Curse III: Blood Sacrifice (1991), the central character is cursed by an 'African witchdoctor', who is subsequently tormented by 
evil spirits. In Outbreak (1995), starring Dustin Hoffman, a Zairean (Congolese) 'juju man' chants impotently while a contagion wipes out his village; American doctors in hazmat suits attempt to address the problem 'scientifically'.

Gaming shows itself to be no different from its forerunners where the recycling of tired socio-cultural stereotypes is concerned. 'Primitive', often malicious and always Other, the 'African witchdoctor' trope's replication and proliferation is seemingly standard within the multi-billion dollar gaming universe (over $\$ 100$ billion in global revenues) (NewZoo 2017). The genre-defining $9{ }^{9}$ Massively Multiplayer Online Role-Playing Game (MMORPG) World of Warcraft (from 2004; ongoing) fields a 'witchdoctor' character who utilises 'a crude yet effective science called juju' (Johnstone 2004). The World of Warcraft sourcebook Magic and Mayhem describes 'witchdoctors' as 'uncommon among other, more civilized races that instead rely on shamanistic aid in times of need'. The 'seething cauldron' belonging to a World of Warcraft 'witchdoctor' is described as bubbling with 'a hallucinogenic mixture of herbs, poisons, crushed insects and other noxious materials' out of which comes a 'Shaka brew' (Johnstone 2004, 55). RuneScape (from 2001; ongoing), which claims on its Twitter page to be 'the world's most popular free MMORPG' with over 260 million accounts, includes 'Papa Mambo', a non-player 'witchdoctor' necromancer who is African in appearance (www.runescape.com). Diablo III, on its release in 2012 the fastestselling computer game on record, also fields 'witchdoctor' characters who are African in appearance and hail from the fictional 'jungle'-dwelling Umbaru 'tribe'. As with 'Papa Mambo', the Diablo III 'witchdoctors' are necromancers who surround themselves with demonic forces (Cain 2012, 142).

The standard portrayal of African healers within Anglo-American popular culture even its newest formats - remains that of the colonial imagination. This in turn is indicative 
of a deeper racism that continues to beset the English-speaking imagination more generally, one that normalises 'whiteness' and Others the rest.

\section{Africa, 'witchcraft', 'witchdoctors' and the 'real world'}

In September 2001, the body of a five-to-six-year-old boy of African heritage was discovered in the River Thames in London (UK). His head, arms, and legs had been removed. An initial line of police enquiry was that the boy's death was a 'muti ${ }^{10}$ murder', a murder said to be committed by a 'witchdoctor' in the interests of harvesting body parts for medicinal purposes (early on in the investigation, London Metropolitan police travelled to South Africa to consult with local counterparts) (Hoskins 2012). Having later discounted this line of enquiry, subsequent police conclusions focused on the killing as a 'ritual sacrifice' involving West African practitioners of 'black magic'.

Supported by an appalled public, horrified police were moved to name the boy Adam - and to lay a wreath in the Thames in his memory. This was without doubt one of the most abject cases of child abuse ever recorded in the UK. At the same time, the 'torso in the Thames' became the basis for a media-exacerbated 'moral panic' feeding off long-entrenched negative constructions of 'African witchdoctors'.

The 'torso in the Thames' generated television documentaries (Channel 4's Torso in the Thames; 2004), books (Richard Hoskins' The Boy in the River; 2012) and substantial media coverage. That the murder remains unsolved has helped to ensure that the case has lingered in the public memory. Hoskins $(2012,247)$, a former missionary and self-described 'multi-cultural expert' who acted as an advisor to the police on the case, suggested that witchcraft-related human sacrifice was increasingly being practiced within the UK. The idea that children in cities like London were being sacrificed by sinister 'African witchdoctors' gripped the public consciousness. The notion that 'African witchdoctors' living in the UK 
were part of a trade in trafficked children continued to generate headlines for years afterwards; 'African children trafficked to UK for blood rituals' was a BBC headline in 2011, with only limited caveats, the report noting that the 'work many of them do is harmless enough'.

This caricature of 'African witchdoctors' as malevolents bent on ritualised violent abuse, is a trope all too readily propagated by the media. A 2002 Guardian report headlined 'Human flesh "on sale in London"', suggesting that there was a high probability that "human flesh is coming into this country' as part of a growing trade in 'bush meat' used by 'African witchdoctors' in preparing traditional medicines (Barnett, Harris and Thompson 2002). Similarly, an undercover investigation on 'African medicine men' in the Evening Standard warned that in London 'suspicion is growing that a trade in human body parts for medicine is either here or on its way' (Boggan 2004).

The idea that African people who consult 'witchdoctors' are, at best, naïve is similarly reinforced. There have been a number of exposés purporting to highlight how unscrupulous 'African witchdoctors' operating in the UK offer 'false hope' to patients suffering from serious ailments while at the same time charging vast sums for spurious treatment. The Daily Mail warns that 'although witchdoctors have long been associated with tribal superstition in remote African villages, few people realise their growing popularity in Britain' (Thompson 2011). In March 2014, the Mirror ran a story headlined 'Revealed: The UK witch doctors exploiting sick Brits by charging $£ 3,000$ to "cure cancer"” (Aldridge 2014), with a similar story appearing in March 2016, headlined 'Fake "witch doctors" exposed as conmen who prey on vulnerable by claiming to cure cancer' (Mega and Hall 2016).

This embodiment of the 'African witchdoctor' as a 'conman' was evident in some of the political 'satire' aimed at President Barrack Obama during his time in office. At the height of debates surrounding 'Obamacare', the controversial (in the United States) 
healthcare provision act brought in by the Obama administration in 2010, the President was frequently portrayed by his opponents as a 'witchdoctor', implying his 'African irrationality'. Posters and placards depicting Obama as a 'witchdoctor' became a fixture at Tea Party rallies, leading to debates as to whether these portrayals were racist - Tea Party representatives conceded that while the depictions might indeed be racist, "they reflect anger about where he [Obama] is leading the country' (Fantz 2009). However, despite intense debates on the acceptability of these portrayals, there was little engagement in the discourse concerning the racism embedded in the trope itself (African people being viewed as irrational); much of the criticism revolved around the fact that such depictions demeaned the President's standing. Tellingly, it was clear that the 'African witchdoctor' caricature immediately resonated with the Tea Party faithful and was one that was at once understood by both Obama's critics and supporters.

The consistency in these twenty-first century media narratives and the extent to which they may help shape and determine debates on what is, and, more importantly, what is not, appropriate when treating illness can be explained, at least in part, by their nineteenth-century origins, and an extant cultural framework that serves to engender uncritical engagement with lurid constructions of wider African-ness.

\section{Conclusion}

Enloe's (1996) call for a detailed political audit of global power structures serves as the basis for this paper. In much the same way that debates surrounding the acceptability of 'golliwogs' and 'blackface' have served to focus attention on the misrepresentation and caricature of black people, a wider debate on outsider perceptions, understandings and distortions of Africa and African people is, to put it mildly, long overdue. While popular culture is often dismissed as unimportant in the world of international politics, it forms an 
important part of the context in which decisions on matters that impact on African countries, and African people, are framed and implemented. Anglo-American popular culture plays a significant role in the production of a 'common sense' that allows people to create a framework through which they understand the world. Problematically, with respect to 'witchdoctors', this 'common sense' imagines African traditional healers as 'primitive' at best, and as charlatans, frauds, and 'evil doers' at worst. Furthermore, African people who engage with traditional healers are viewed as uneducated, superstitious, naïve, and childlike. That so many representations of African people remain shaped and informed by colonial tropes has 'real world' consequences, given that 'development' is a project largely conceived of and 'delivered' by the Global North. It is difficult to see how 'development' as a practice can impact positively in Africa when the 'common sense' view of African people in the Global North continues to be so anchored in colonial-era racist stereotypes. While popular culture is not 'high politics', its impact in this regard should not be understated

\section{Notes}

${ }^{1}$ This article is informed, in part, by research trips to Ghana (2017), Kenya (2014, 2015, 2017), Nigeria (2013), Somalia (2015, 2016), South Africa (2010, 2012, 2014, 2017) and to Native American nations in the United States (2015, 2017). Interviews were conducted with a range of healthcare providers, traditional healers, public health workers, campaigners and academics. While not the basis for this article, these data contribute to the argument outlined, as do field notes.

${ }^{2}$ Based on personal interviews with clients of traditional healers in Kenya, Nigeria, Somaliland and South Africa.

${ }^{3}$ This is not to suggest that the IHS is in any way perfect; the service tends to be chronically underfunded and understaffed (Flint 2015). 
${ }^{4}$ Interviews with medical practitioners in Washington State connected to the IHS relay a similar, albeit anecdotal position.

${ }^{5}$ Based on personal interviews with a range of traditional healers from Malawi, Nigeria, Uganda, and South Africa.

${ }^{6}$ See for example Hewitt's (2006) argument that 'good government' in a development context represents a continuation, in many respects, of British colonial policy from the 1930s. Likewise, Kothari (2009) highlights continuities between colonial officers and development professionals.

${ }^{7}$ Howard is probably most famous for his Conan the Barbarian series, in which magic and sorcery also play an important role.

${ }^{8}$ As of 2017, Wilbur Smith's novels had sold a total of 130 million copies; at 84, he signed a new book deal estimated at £10m (https://www.ft.com/content/1d964414-5501-11e7-80b69bfa4c1f83d2).

${ }^{9}$ Data with respect to MMORPGs is somewhat difficult to pin down, so it is difficult to determine with any certainly which games attract the most subscribers/players.

${ }^{10}$ Muti (or muthi) can refer to either 'medicine' or 'poison', and, consequently, depending on who is employing it, can be used in a positive sense (ie to heal) or negatively (ie to bring about death or misfortune) (Ashforth 2005). The term 'muti murder' is one often used in countries like South Africa to describe killings deemed to have a 'ritualistic' element.

\section{Disclosure statement}

No potential conflict of interest was reported by the author.

\section{Acknowledgements}

I would like to thank Jill Payne, SPAIS, University of Bristol, for her help with this paper. 


\section{Author}

Adrian Flint is a Senior Lecturer in Development Politics at the School of Sociology, Politics and International Studies (SPAIS) at the University of Bristol.

\section{Bibliography}

Aldridge, G. 2014. "Revealed: The UK witch doctors exploiting sick Brits by charging $£ 3,000$ to "cure cancer'”, The Mirror, March 15 http://www.mirror.co.uk/news/uknews/british-witch-doctors-charge-3000-3247614

Allende, I. 2005. Forest of the Pygmies. New York: Harper Perennial.

Adorno, T. W. and Horkheimer, M. 1979. Dialectic of Enlightenment. London: Verso.

Ashforth, A. 2000. Madumo: A Man Bewitched. Chicago Ill: University of Chicago Press.

Ashforth, A. 2001. "AIDS, witchcraft, and the problem of power in post-apartheid South Africa”, School of Social Sciences, Occasional Paper, No. 10, May, Institute for Advanced Studies.

Ashforth, A. 2005. "Muthi, Medicine and Witchcraft: Regulating 'African Science' in PostApartheid South Africa?", Social Dynamics, 31(2): 211-242

Barnett, A., Harris, P. and Thompson, T. 2002. "Human flesh 'on sale in London'”, The Guardian, November 3 https://www.theguardian.com/uk/2002/nov/03/ukcrime.antonybarnett Burton, R. F. 1856. First Footsteps in East Africa. A Public Domain Book: Kindle Edition.

Cain, D. 2012. Diablo III: Book of Cain. San Rafael, California: Insight.

Conrad, J. 1999. Heart of Darkness and Other Stories, Ware: Wordsworth Classics.

Devisch, R. 2005. "Cultural modes of comprehending and healing insanity: The Yaka of DR Congo", Africa Development, 30(3): 93-111.

Dickinson, D. 2014. A Different Kind of AIDS: Folk and Lay Theories in South African Townships, Jacana Media: Sunnyside. 
Duffield, M. 2007. Development, Security and Unending War: Governing the World of Peoples. Cambridge: Polity Press.

Enloe, C. 1996. "Margins, Silences and Bottom rungs: how to overcome the underestimation of power in the study of international relations", in Smith, S., Booth, K. and Zalewski, M. (eds) International Theory: Positivism and Beyond, Cambridge: Cambridge University Press: 186-202.

Fanon, F. (1965) A dying colonialism. New York: Grove Press.

Fantz, A. 2009. Obama as witch doctor: Racist or Satirical? CNN.com. https://edition.cnn.com/2009/POLITICS/09/17/obama.witchdoctor.teaparty/

Farmer, N. 1994. The Ear, the Eye and the Arm. New York: Puffin.

Flint, A. G. 2015. "Traditional Healing, Biomedicine and the Treatment of HIV/AIDS: Contrasting South African and Native American Experiences", International Journal of Environmental Research and Public Health, 12(4): 4321-4339.

Flint, A. G. and Hewitt, V. M. 2015. "Colonial Tropes and HIV/AIDS in Africa: Sex, Disease and Race", Commonwealth \& Comparative Politics, 53(3): 294-314.

Flint, A. G. and Payne, J. 2013. "Reconciling the Irreconcilable? HIV/AIDS and the Potential for Middle Ground between the Traditional and Biomedical Healthcare sectors in South Africa", Forum for Development Studies, 40(1): 47-68.

Gramsci, A. 2000. The Antonio Gramsci Reader: Selected Writings 1916-1935, New York: New York University Press.

Hayder, M. 2008. Ritual, London: Bantam Press.

Haggard, H. R. 1885. King Solomon's Mines. London: Cassell and Company, Limited http://www.gutenberg.org/files/2166/2166-h/2166-h.htm

Haggard, H. R. 1896. The Wizard. London: Longmans, Green, and Co. http://www.gutenberg.org/files/2893/2893-h/2893-h.htm 
Hall, S. 1997. Representation: Cultural Representations and Signifying Practices, London: Sage.

Hewitt, V. M. 2006. “A Cautionary Tale: Colonial and Post-colonial Conceptions of Good Government and Democratisation in Africa", Commonwealth \& Comparative Politics, 44(1): 41-61.

Hoskins, R. 2012. The Boy in the River: A Shocking True Story of Murder and Sacrifice in the Heart of London. Basingstoke and Oxford: Pan.

Howard, R. E. 1928. "Red Shadows" in Weird Tales http://gutenberg.net.au/ebooks06/0607331.txt

Howard, R. E. 1930. "Hills of the Dead", In Weird Tales http://gutenberg.net.au/ebooks06/0600871.txt

Howard, R. E. 2007. The Best of Robert E. Howard Volume 1: Crimson Shadows. New York Ballantine.

Iroegbu, P. 2005. "Healing insanity: skills and expert knowledge of Igbo healers", Africa Development, 30(3): 78-92.

Janzen, J. 1992. Ngoma: Discourses of Healing in Central and Southern Africa. University of California Press.

Johnstone, M. 2004. Warcraft: Magic and Mayhem, Stockholm: Arthaus.

Kim, C. and Kwok, Y. S. 1998. "Navajo Use of Native Healers", Archives of Internal Medicine, 158: 2245-2249.

Kingsolver, B. 1998. The Poisonwood Bible. New York: HarperCollins.

Kothari, U. 2009. "Spatial Practices and Imaginaries: Experiences of Colonial Officers and Development Professionals" in Duffield, M. and Hewitt, V. (eds) Empire, Development and Colonialism: The Past in the Present. Woodbridge: James Currey: 161-175.

Kunzru, H. 2003. The Impressionist. London: Penguin. 
Livingstone, D. 1857. Missionary Travels and Researches in South Africa. A Public Domain Book: Kindle edition.

Livingstone, D. 1875. A Popular Account of Livingstone's Expedition to the Zambesi and its Tributaries. A Public Domain Book: Kindle edition.

Mega, M. and Hall, E. 2016. "Fake 'witch doctors' exposed as conmen who prey on vulnerable by claiming to cure cancer", The Mirror, March 3 http://www.mirror.co.uk/news/uk-news/fake-witch-doctors-exposed-conmen-7490835

Mkhize, N., Dumisa, N. and Chitindingu, E. 2014. "Democratising Access and Success: IsiZulu Terminology Development and Bilingual Instruction in Psychology at the University of KwaZulu-Natal”, Alternation, 13 (Special Edition): 128-124.

Mpofu, E., Peltzer, K., and Bojuwoye, O. 2011. "Indigenous Healing Practices in SubSaharan Africa", in Mpofu, E. (ed.) Counselling People of African Ancestry. Cambridge: Cambridge University Press: 3-21.

Nattrass, N. 2008. "Who Consults Sangomas in Khayelitsha? An Exploratory Quantitative Analysis", Social Dynamics - A Journal of African Studies, 31(2): 161-182.

NewZoo. 2017. “2017 Global Games Market Report: Trends, Insights and Projections Toward 2020”, http://progamedev.net/wpcontent/uploads/2017/06/Newzoo_Global_Games_Market_Report_ 2017_Light.pdf

Ngubane, H. (1977) Body and Mind in Zulu Medicine (London: Academic Press).

Okere, T. (2005) “Is There One Science, Western Science?", Africa Development, 30(3): 2034.

Park, M. 2002. Travels in the Interior of Africa. Ware: Wordsworth Editions.

Ramose, M. B. 2016. "But the man does not throw bones", Alternation, 18 (Special Edition): $60-71$. 
Rice Burroughs, E. 1919. Jungle Tales of Tarzan. Chicago Ill: A. C. McClurg.

Rice Burroughs, E. 2014. The Great Book of Tarzan. Floyd VA: Wilder Publications.

Rowley, C. 2010. "Popular Culture and the Politics of the Visual", in Shepard, L. (ed)

Gender Matters in Global Politics: A Feminist Introduction to International Relations.

Taylor and France: 361-374.

Said, E. W. 1995. Orientalism: Western Conceptions of the Orient. London: Penguin.

Shapiro, M. 1992. Reading the Postmodern Polity: Political Theory as Textual Practice.

Minneapolis MN: University of Minnesota Press.

Smith, W. 1980. A Falcon Flies. London: Pan.

Smith, W. 1981. Men of Men. London: Pan.

Smith, W. 1984. The Leopard Hunts in Darkness. London: Pan.

Smith, W. 1987. Rage. London: Pan.

Smith, W. 1991. Elephant Song. London: Pan.

Smith, W. 2009. Assegai. London: Pan.

Stinetorf, L. A. 1950. Witch Doctor. Philadelphia PA: The Westminster Press.

The Times. 1850. "Report: State of the Cape frontier". December 20.

The Times. 1878a. “The Caffre Outbreak". March 22.

The Times. 1878b. "The Caffre War”, May 21.

The Times. 1883. "Report: South Africa". November 7.

The Times. 1894. “The Matabele campaign”, March 24.

The Times. 1897. "Witchcraft in Rhodesia”, November 4.

Wasunna, A. A. 2012. "The Discourses of Practitioners in Africa", in Baker, R. and McCullough, L. (eds) The Cambridge World History of Medical Ethics. Cambridge: Cambridge University Press: 311-323.

Wells, H. G. 1897. The Plattner Story and Others. London: Methuen \& Co. 
Weber, C. 2014. International relations theory: a critical introduction, Oxford: Routledge.

Weldes, J. 1999. “Going Cultural: Star Trek, State Action, and Popular Culture”, Millennium - Journal of International Studies, 28(1): 117-134.

Weldes, J. 2003. "Popular Culture, Science Fiction, and World Politics: Exploring Intertextual Relations" in Weldes, J. (ed) To Seek Out New Worlds Science Fiction and World Politics, Basingstoke: Palgrave Macmillan: 1-27.

WHO. 2002. "WHO Traditional Medicine Strategy 2002-2005”, World Health Organisation: Geneva, Switzerland.

WHO. 2008. "Traditional medicine", Fact sheet No. 134, December.

WHO. 2019. "WHO global report on traditional and complementary medicine 2019”, World Health Organisation: Geneva, Switzerland. 
